\title{
Observations during an Itch-Inducing Lecture
}

\section{Beobachtungen während eines J uckreiz-induzierenden Vortrages}

\author{
V. Niemeier J . Kupfer ${ }^{\mathrm{b}}$ U. Gieler \\ aZentrum für Dermatologie und Andrologie, \\ ${ }^{b}$ Abteilung für Medizinische Psychologie am Zentrum für Psychosomatische Medizin, \\ 'Zentrum für Psychosomatische Medizin - Psychosomatische Dermatologie der J ustus-Liebig-Universität Gießen
}

\section{Key Words \\ Skin disease and psyche $\cdot$ Itching $\cdot$ Scratching $\cdot$ Pruritus}

\section{Summary}

Itching is a subjective symptom which is reported to occur in $75 \%$ of all skin diseases. Although repeatedly postulated, psychological correlations with itching have rarely been investigated. In cooperation with a public television company which prepared a scientific program on itching, interested persons were invited to participate in a public lecture: 'Itching - what's behind it?'. The aim of the lecturers was to initially present an itch-inducing lecture to the still uninformed audience, followed by a neutral verbal and visual stimulation to feel comfortable. Accordingly, the first part included slides that induce itching, while the second part showed slides that induce relaxation and sense of well-being. At the same time, the listeners' tactile reactions were recorded by television cameras all around to allow rating of the scratch impulses. In an ABA design could be shown that itching measured by self-rating scales ( $n=24$ ) could be induced by the itch-inducing verbal and visual intervention. The frequency of scratching recorded by the television cameras was evaluated independently by two raters. The t-test confirmed a significant mean difference in the expected direction. In total, this study confirms the previous assumption that itching can be induced by psychic factors.

\section{Schlüsselwörter \\ Hauterkrankung und Psyche · J uckreiz · Kratzen · Pruritus}

\section{Zusammenfassung}

J uckreiz ist ein subjektives Symptom, welches bei $75 \%$ aller Hauterkrankungen angegeben wird. Psychologische Zusammenhänge des J uckreizes, obwohl immer wieder postuliert, sind bisher selten experimentell untersucht worden. In der vorliegenden Studie konnte untersucht werden, inwieweit eine verbale und visuelle Intervention, die juckreizauslösende Reize vermittelt, bei Versuchspersonen J uckreiz und Kratzen induziert. In Zusammenarbeit mit einer öffentlichen Fernsehanstalt, die eine Wissenschaftssendung zum Thema J uckreiz vorbereitete, wurden in einer öffentlichen Ankündigung die Teilnehmer zu einer Veranstaltung eingeladen mit dem Thema: «J uckreiz - Was steckt dahinter?». Ziel des Vortrags eines der Autoren war dabei, den vor dem Vortrag völlig uninformierten Zuhörern zunächst einen juckreizinduzierenden Inhalt zu präsentieren und in einem zweiten Abschnitt eine eher neutrale Stimulation, um ein Wohlbefinden in der Haut hervorzurufen. Entsprechend wurden im ersten Teil Diapositive gezeigt, die visuell juckreizinduzierend wirken sollten, im zweiten Teil Diapositive, die eine entspannende und Wohlgefühl auslösende Stimulation induzieren sollten. Gleichzeitig wurden per Fernsehkameras, die den gesamten Vortragsraum erfaßten, die taktilen Reaktionen der Teilnehmer festgehalten und für ein entsprechendes Rating der Kratzimpulse durch Rater dokumentiert. In einem ABA-Design konnte gezeigt werden, daß J uckreiz, gemessen durch Selfrating-Skalen, durch eine verbale und visuelle Intervention ausgelöst werden kann. Der t-Test bestätigte einen signifikanten Mittelwertsunterschied in der angenommenen Richtung. Insgesamt können mit dieser Studie frühere Annahmen, daß J uckreiz auch psychisch induziert werden kann, bestätigt werden.

\begin{tabular}{ll}
\hline KARGER & ○ 1999 S. K arger G mbH , Freiburg \\
Fax +49 761 45207 14 & A ccessible online at: \\
$\begin{array}{l}\text { E-mail kargergmbh@aol.com } \\
\text { www.karger.com }\end{array}$ & http://B ioM edN et.com/karger
\end{tabular}

Prof. Dr. U we Gieler

Klinik für Psychosomatik und Psychotherapie

Psychosomatische D ermatologie

L udwigstraße 76, D-35392 G ießen (G ermany)

Tel. +49-641-99-45650, F ax -45659

E-mail: U we.G ieler@psycho.med.uni-giessen.de 


\section{Introduction}

Itching is a subjective symptom which is reported to occur in $75 \%$ of all skin diseases [1, 3]. I tching is defined as a sensation associated with an impulse to scratch [8, 12]; it can only be induced in skin, conjunctiva and mucous membranes. Induction of itch by mechanical, thermal, chemical and electrical stimulation of the skin is generally accepted [10]. Psychological factors of itching, though often postulated, have only rarely been investigated in experimental studies [13].

Intensification of experimentally induced itch under stress conditions was observed by Fjellner and A rnetz [5] in 10 volunteers. Sheedan-D are et al. [16] demonstrated an association between generalized itch and depression and anxiety by means of a test psychological examination of 34 patients. Similar results in patients with psoriasis were obtained by $\mathrm{G}$ upta et al. [6].

The possibility of psychic induction of itching has repeatedly been reported in the popular press and numerous surveys [11, 12]. A possible explanation might be conditioned histamine release (as confirmed in animal experiments) [15]. In an experimental study using a histamine prick test, $\mathrm{H}$ ermanns and Scholz [9] investigated the influence of cognitive evaluation patterns on the intensity of itching and weal reaction. Volunteers who had been instructed to think in relative terms reacted less intensely to the prick test than those directed towards a dramatizing cognition. A purely mental induction of itching was pointed out by R echenberger et al. [13]. O nly few studies have discussed the possibility of mental induction of itching. R obinson et al. [14] reported about psychogenic epidemic disease with itching and skin rash associated with stress at a primary school. Sim and E cht [17] described the eruption of itching skin lesions in a group of workers, whereby it could not be excluded in this case report that pruritus was caused in some of the workers by contact with fibrous glass fibres.

The present study was designed to investigate, to our knowledge for the first time, whether or not itching and scratching can be induced in volunteers by purely verbal and visual intervention. Based on the well-known experience in dermatological teaching that lectures on typical itching dermatoses (scabies, pediculosis and others) create unrest among the listeners, this phenomenon was to be objectified in a quasi-experimental approach.

\section{Method}

In cooperation with a public television company which prepared a scientific program on itching, interested persons were invited to participate in an public lecture: 'I tching - what's behind it?'. The aim of the lecturers was to initially present an itch-inducing lecture to the still uninformed audience, followed by a neutral verbal stimulation to feel comfortable. A ccordingly, the first part included slides that induce itching (pictures of fleas, mites, scratch marks on the skin, allergic reactions etc.), while the second part showed slides that induce relaxation and sense of well-being (pictures of baby skin, soft down, bathers, mother with child in her arms etc.) A the same time, the listeners' tactile reactions were recorded by television cameras all around to allow rating of the scratch impulses. To conceal this fact and to keep the participants neutral, the television team stated that the lecturer would be taken for their program and the audience should not care about their presence. A the end of the lecture the listeners were informed about the real issues of the experiment and had the opportunity for discussion.

A three different times the participants completed a short questionnaire. These were distributed and collected before the lecture ( $T$ 1), after the first part with the itch-inducing component ( $T$ 2) and after the second part with the relaxing component (T 3) (A BA design).

$B$ ecause the study situation required short questionnaires, the participants were merely asked to mark questions for age and sex, existing skin disease and present sensation of itching and scratching, on a visual analogue scale from 1 to 10 .

Furthermore, their real scratch reactions were documented by means of the television recording. Two raters were trained for several hours to record each scratch reaction and rubbing among the persons observed. For evaluation of the recording, the raters independently assessed each participant for $10 \mathrm{~min}$ each during the first and second part of the lecture. Subsequently inter-rater correlations were calculated. The raters have been blind and they did not know the design and which 10 min they just evaluated.

A total of 32 persons listened to the lecture; 25 of them (11 women, 13 men, 1 without statement) completed all three questionnaire; 14 stated to suffer from a skin disease, 11 stated to have none. The average age in the group without skin diseases was 43.1 years ( $S D=12.65)$, in the group with skin diseases it was 36.4 years ( $S D=14.7$ ).

The data were evaluated by analysis of variance with repeated measures.

\section{Results}

Q uestionnaire statements concerning itching and scratching:

A high correlation was observed among the participants' statements concerning itching and scratching $\left(r_{i t c h i n g}\right.$, scratching $=$ $0.72 ; p<0.000$ ) so that only the results of itching are shown in the following:

First it was tested whether the experienced itching was dependent on age or sex. Since no dependence was shown for these variables, they were not considered further.

In the following, the experienced itching is shown in relation to existing or non-existent skin disease.

The analysis of variance with repeated measures (skin disease yes-no, 3 times) revealed only a tendency to distinguish be- 
Fig. 1. Change of itching sensations depending on skin disease and time of measurement ( $\mathrm{T} 1$ = baseline; $\mathrm{T} 2$ = after itch induction; $\mathrm{T} 3=$ after relaxation).
Fig. 2. A verage frequency of scratching per participant during itch induction and during relaxation $[\mathrm{T}(16)=2.80 ; \mathrm{p}=0.013]$.
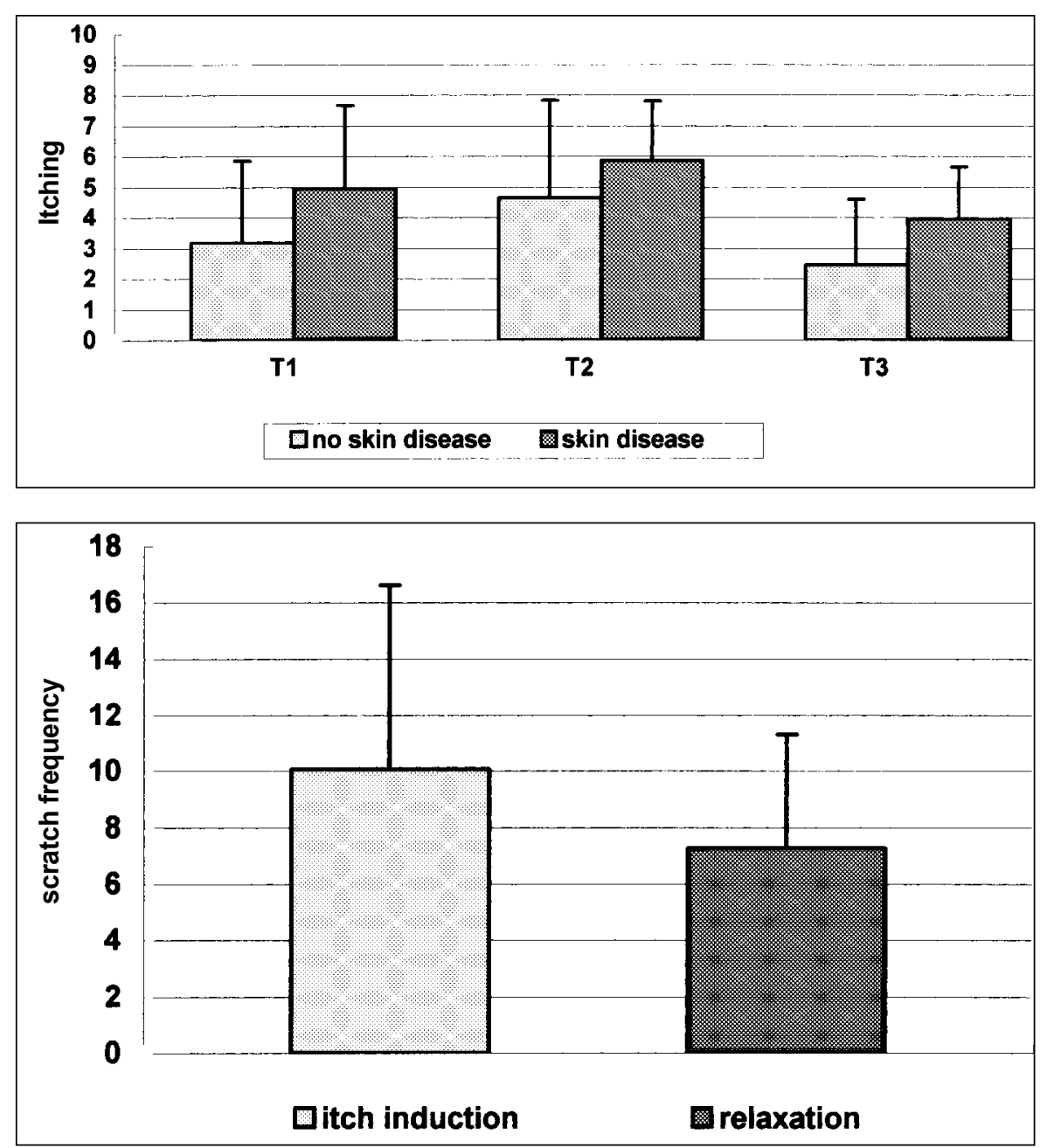

tween volunteers with skin disease and those without $[F(1)=$ 3.47; $p=0.075$ ]. H owever, the time effect was highly significant $[F(2)=8.98 ; p=0.001]$, while the interaction effect was not significant $[F(2)=0.15 ; p=0.86]$.

A mong the participants without skin disease, itching increased from $3.18(\mathrm{SD}=2.68)$ at time $\mathrm{T} 1$ to $4.64(\mathrm{SD}=3.20$ ) at time T 2 and decreased again to $2.45(\mathrm{SD}=2.16)$ at time T3. The mean value of itching for participants with skin diseases was $4.93(S D=2.73$ ) at time $T 1$, increasing to $5.86(S D=1.96)$ at time $\mathrm{T} 2$ and decreasing to $3.96(\mathrm{SD}=1.69)$ at time T3. The initial hypothesis that the first part of the lecture would have an itch-inducing effect, was confirmed (fig. 1).

H owever, the initial value of itching at time $\mathrm{T} 1$ (4.16, SD = 2.79) is already on a relatively high level and significantly higher than the final value at time T3 $(3.30, S D=2.02)$. It is possible that merely the expectations to go to a lecture about itching or a public event with a television team have caused increased sensation of itching.

The frequency of scratching taken by the television cameras was evaluated independently by two raters. Complete records were available for 17 persons who had been permanently present in the focus of the cameras. The inter-rater correlation was $r=0.91$ ( $p<0.001)$ for both parts of the lecture $(r=0.95$ for part $1, r=0.85$ for part $2, p<0.001$ each).

Because of the high inter-rater correlation, the data for the following t-test could be pooled. The t-test confirmed a significant mean difference in the expected direction $(T(16)=2.80$, $p=0.013$; see fig. 2). The mean frequency of scratching during the first part of the lecture was 10.1 (SD $=6.6$ ), as against 7.3 (SD $=4.1$ ) during the second part.

Since the questionnaires had been completed anonymously, no differentiation was possible between persons with skin diseases and those without.

\section{Discussion}

D espite of numerous studies, itching can only be assessed subjectively; the fact remains that it is still defined according to $\mathrm{H}$ affenreffer [7] who described it as an uncomfortable sensa- 
tion that induces craving for scratching. A nimal models for investigation of pruritus have not been established, yet [19]. Therefore, measurement of itch has only been possible by use of different scales reflecting subjective itching [18]. Further measurement of itch can only be achieved by observation of the scratch behavior.

A lthough it is generally known that lectures and reports about pruritus often produce a feeling of itching among the listeners, this observation has (strangely enough) not been investigated in experimental studies. Therefore, the present study has shown for the first time that itching can be induced by psychic trigger factors. Increased values after induction of itch were recorded from the questionnaires and the scratching behavior of the participants. There were hardly any differences between persons with skin diseases and those without. In total, this study confirms the previous assumption that itch- ing can be induced by psychic factors, and explains individual case reports about epidemic diseases with psychogenic itch.

Psychic induction of itching might be caused by conditioned histamine release, which, however, remains to be investigated in human experiments [15].

It is remarkable that itching was less frequently experienced during the second part as compared to the initial values. It appears that relieving verbal and visual intervention may reduce itching and scratching impulses. A similar phenomenon was observed in patients with atopic eczema who had been instructed in autogenic training [4].

In further studies it should be clarified whether itching and scratching are more influenced by visual or verbal intervention. B uske-K irschbaum et al. [2] demonstrated that patients with recurrent herpes labialis relapsed after they had been shown loathsome pictures.

B ecause of the small number of participants and the high age differences, our results are only partly transferable to other groups. To elucidate the phenomenon of mental induction of itch, further experimental studies are necessary and desirable.

\section{References}

1 Bernhard J D : Itch - M echanism and M anagement of Pruritus. N ew Y ork, M c G raw-H ill, 1994.

2 Buske-K irschbaum A, Geiben C, Wermke KM, Pirke C, K irschbaum C, H ellhammer D H : M odulation of the recurrence of herpes labialis by experimentally induced disgust. Poster at the 7th Int. Congress on Dermatology and Psychiatry 2.4.10.1997 A bstract B ook. H alle, 1997, p 30.

3 D uperat B, Pringuet R: Psoriasis pustuleux suivi pendant 5 annèes. $D$ evelopement precoce $d$ 'une retraction reflexe des mains. Survenue de manifestations viserales. R ole eventuels d une inoculation de facteurs psychiques. Bull Soc Franc Derm Syph 1962;69:768.

4 Ehlers A, Stangier U, G ieler U : Treatment of A topic D ermatitis: A Comparison of Psychological and Dermatological A pproaches to R elapse Prevention. J Consult Clin Psychol 1995;63:624-635.

5 Fjellner B, A rnetz B: Psychological predictors of pruritus during mental stress. A cta Derm Venerol 1985;65:504-735.

6 G upta M A , G upta A K, K irkby S, Weiner HK, M ace TM, Schork NJ, Johnson EH, Ellis CN, Voorhees $\mathrm{J} \mathrm{J}$ : Pruritus in psoriasis - a prospective study of some psychiatric and dermatologic correlates. A rch D ermatol 1988;124:1052-1057.
$7 \mathrm{H}$ affenreffer S: De pruritu, in Nosodochium, in quo cutis, eiqque adharentium partium, affectus omnes, singulari methodo, et cognoscendi et curandi fidelissime traduntur. U Im, K ühn B., 1660, pp 98-102.

$8 \mathrm{H}$ andwerker $\mathrm{HO}$ : Pathophysiologie des Juckreizes; in $\mathrm{G}$ arbe $\mathrm{C}, \mathrm{R}$ assner $\mathrm{G}$ (eds): D ermatologie - L eitlinien und $Q$ ualitätssicherung für Diagnostik und Therapie. Springer-Verlag Berlin - Heidelberg 1998; pp 43-45.

9 Hermanns N, Scholz OB: Psychologische E inflüsse auf die atopische D ermatitis - eine verhaltensmedizinische Sichtweise; in Gieler $U$, Stangier $U$, Brähler E (eds): Jahrbuch der medizinischen Psychologie B and 9, G öttingen, H ogrefe, 1993.

$10 \mathrm{M}$ agerl, W: Neurophysiologie des J uckens. A llergologie 1991;14:395-405.

$11 \mathrm{M}$ arghescu S: Pruritus sine materia. Z Hautkr 1993;68:335-337.

12 M etze D, R eiman S, L uger T: Juckreiz - Symptom oder K rankheit; in Plewig G, Przybilla (eds): Fortschritte der praktischen D ermatologie und Venerologie 1997. Berlin, Springer, 1997, pp 77-86.
13 Rechenberger I: Pruritus as a psychic phenomenon. M ünch M ed W schr 1981;123:1005-1006.

14 R obinson P, Szewczyk M, Haddy L, Jones P, Harvey $W$ : $O$ utbreak of itching and rash. E pidemic hysteria in an elementary school. A rch Intern Med 1984;144:1959-1962.

15 Russell M, Dark KA, Cummins RW, Ellman G, Callaway $E$, Peeke H V S: L earned histamine release. Science 1984;225:733-734.

16 Sheehan-Dare RA, Henderson MJ, Cotterill JA: A nxiety and depression in patients with chronic urticaria and generalized pruritus. $\mathrm{Br} J$ Dermatol 1990;123:769-774.

17 Sim M R, E cht A : A n outbreak of pruritic skin lesions in a group of laboratory workers - a case report. O ccup M ed 1996;46:235-238.

18 Wahlgren CF. M easurement of Itch. Semin D ermatol 1995;14:277-284.

19 Woodward DF, Conway JL, Wheeler LA. Cutaneous itching models; in $\mathrm{Maibach} \mathrm{HI}$, Lowe $\mathrm{NJ}$ (eds): M odels in Dermatology (vol 1). Basel, Karger, 1985, pp 187-195. 